\title{
Binding of the kringle-2 domain of human plasminogen to streptococcal PAM-type M-protein causes dissociation of PAM dimers
}

\author{
Olawole Ayinuola ${ }^{1}$, Yetunde Ayinuola ${ }^{1}$, Cunjia Qiu ${ }^{1}$, Shaun Lee ${ }^{1}$, Victoria Ploplis ${ }^{1}$, and \\ Francis Castellino ${ }^{1}$ \\ ${ }^{1}$ University of Notre Dame
}

September 25, 2021

\begin{abstract}
M-protein (PAM) largely contributes to the pathogenesis of Pattern D Group A Streptococcus pyogenes (GAS). However, the mechanism of complex formation is unknown. In a system consisting of a Class II PAM from Pattern D GAS isolate NS88.2 (PAMNS88.2), with one K2hPg binding a-repeat in its A-domain, we employed biophysical techniques to analyze the mechanism of the $\mathrm{K} 2 \mathrm{hPg} / \mathrm{PAMNS} 88.2$ interaction. We show that apo-PAMNS88.2 is a coiled-coil homodimer $\left(\mathrm{M} . \mathrm{Wt} .{ }^{\sim} 80 \mathrm{kDa}\right)$ at $4^{\circ} \mathrm{C}$ - $25^{\circ} \mathrm{C}$, and is monomeric (M.Wt. $\sim 40 \mathrm{kDa}$ ) at $37^{\circ} \mathrm{C}$, demonstrating a temperature-dependent dissociation of PAMNS88.2 over a narrow temperature range. PAMNS88.2 displayed a single tight binding site for $\mathrm{K} 2 \mathrm{hPg}$ at $4^{\circ} \mathrm{C}$, which progressively increased at $25^{\circ} \mathrm{C}$ through $37^{\circ} \mathrm{C}$. We isolated the $\mathrm{K} 2 \mathrm{hPg} / \mathrm{PAMNS} 88.2$ complexes at $4^{\circ} \mathrm{C}, 25^{\circ} \mathrm{C}$, and $37^{\circ} \mathrm{C}$ and found molecular weights of $\sim 50 \mathrm{kDa}$ at each temperature, corresponding to a $1: 1$ (m:m) K2hPg/PAMNS88.2 monomer complex. hPg activation experiments by streptokinase demonstrated that the hPg/PAMNS88.2 monomer complexes are fully functional. The data show that PAM dimers dissociate into functional monomers at physiological temperatures or when presented with the active hPg module $(\mathrm{K} 2 \mathrm{hPg})$ showing that PAM is a functional monomer at $37^{\circ} \mathrm{C}$.
\end{abstract}

\section{Hosted file}

Microbiology Open.pdf available at https://authorea.com/users/437766/articles/539174-bindingof-the-kringle-2-domain-of-human-plasminogen-to-streptococcal-pam-type-m-protein-causesdissociation-of-pam-dimers 
A

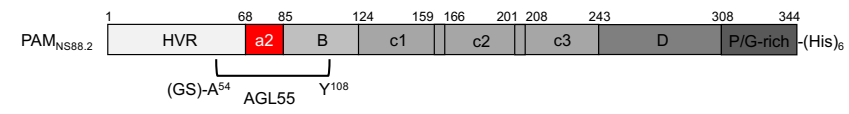

B
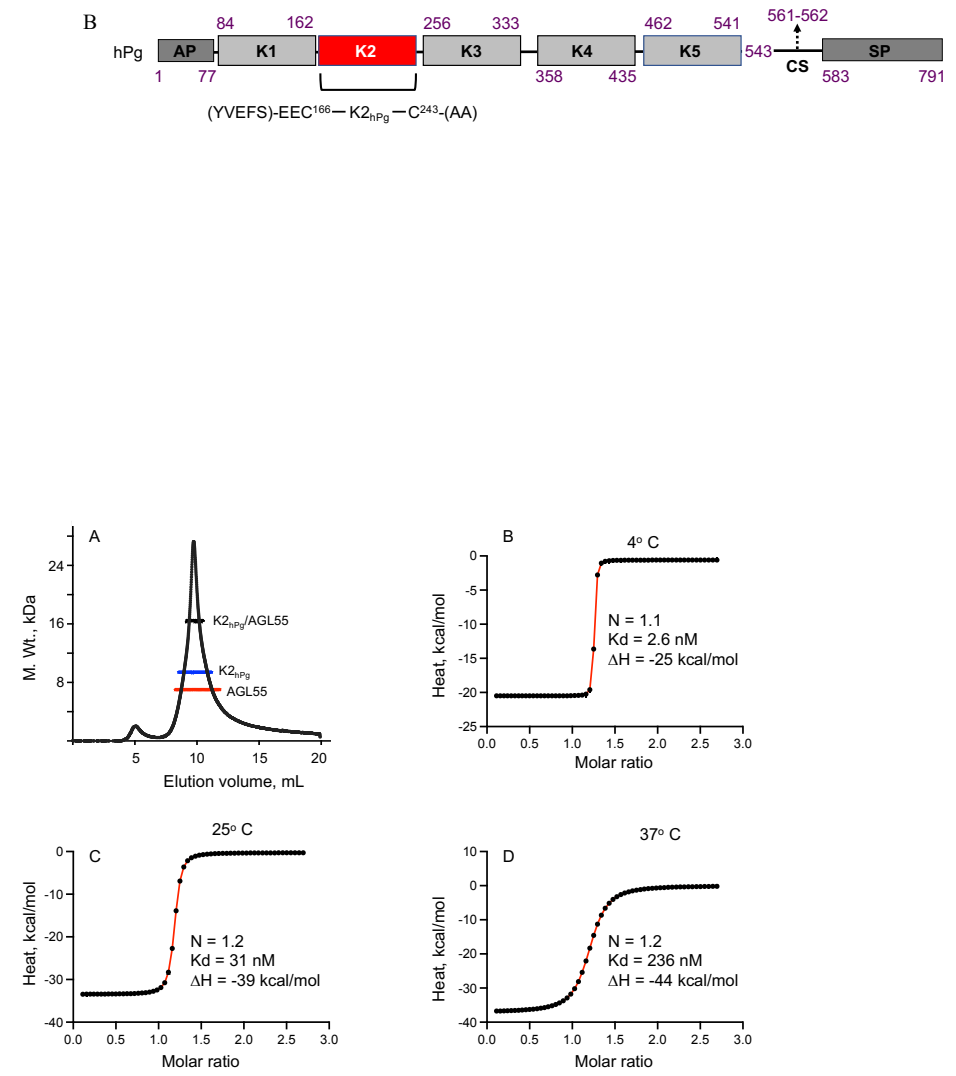

\section{Hosted file}

Figure_3.pdf available at https://authorea.com/users/437766/articles/539174-binding-ofthe-kringle-2-domain-of-human-plasminogen-to-streptococcal-pam-type-m-protein-causesdissociation-of-pam-dimers 

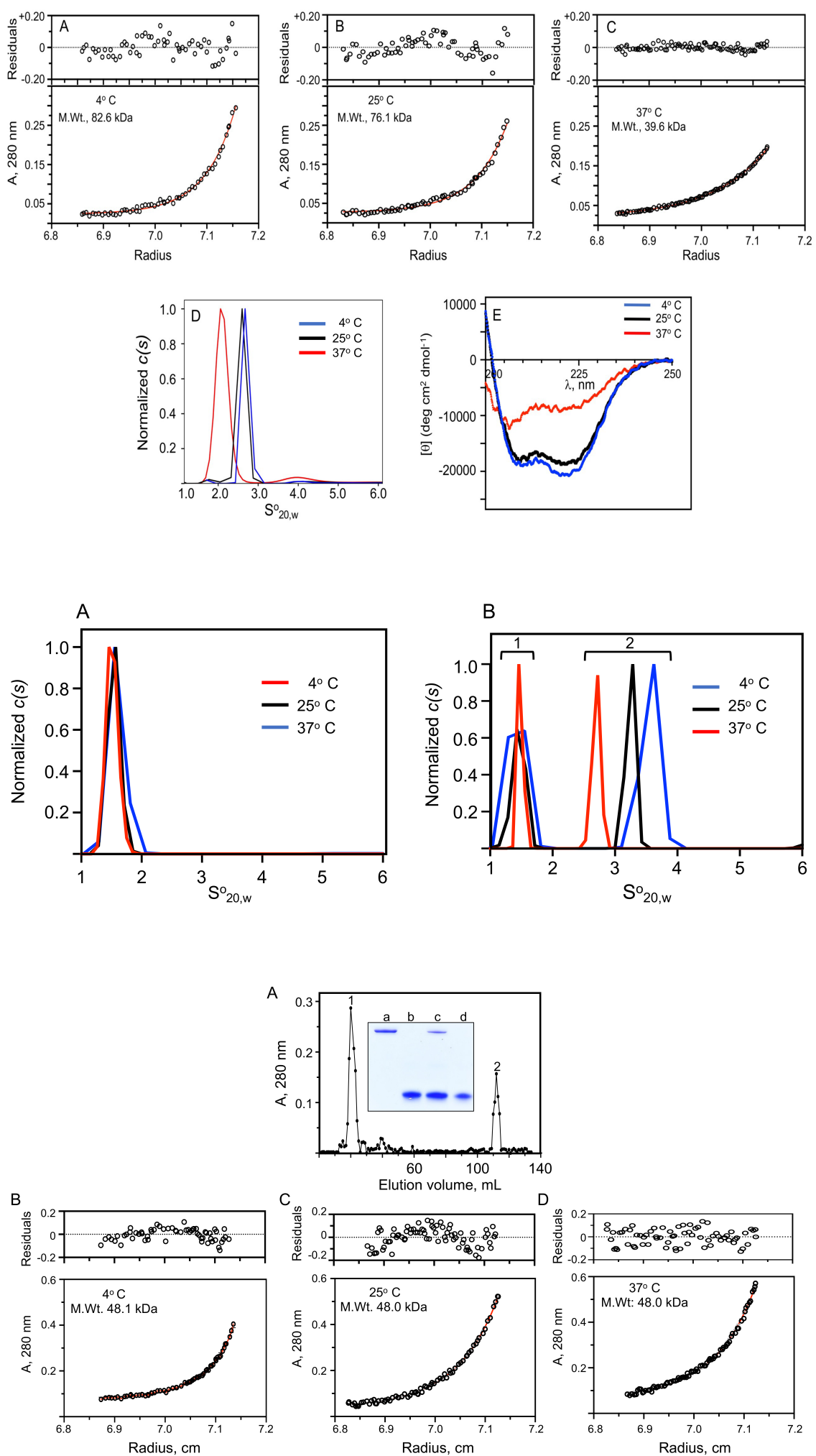

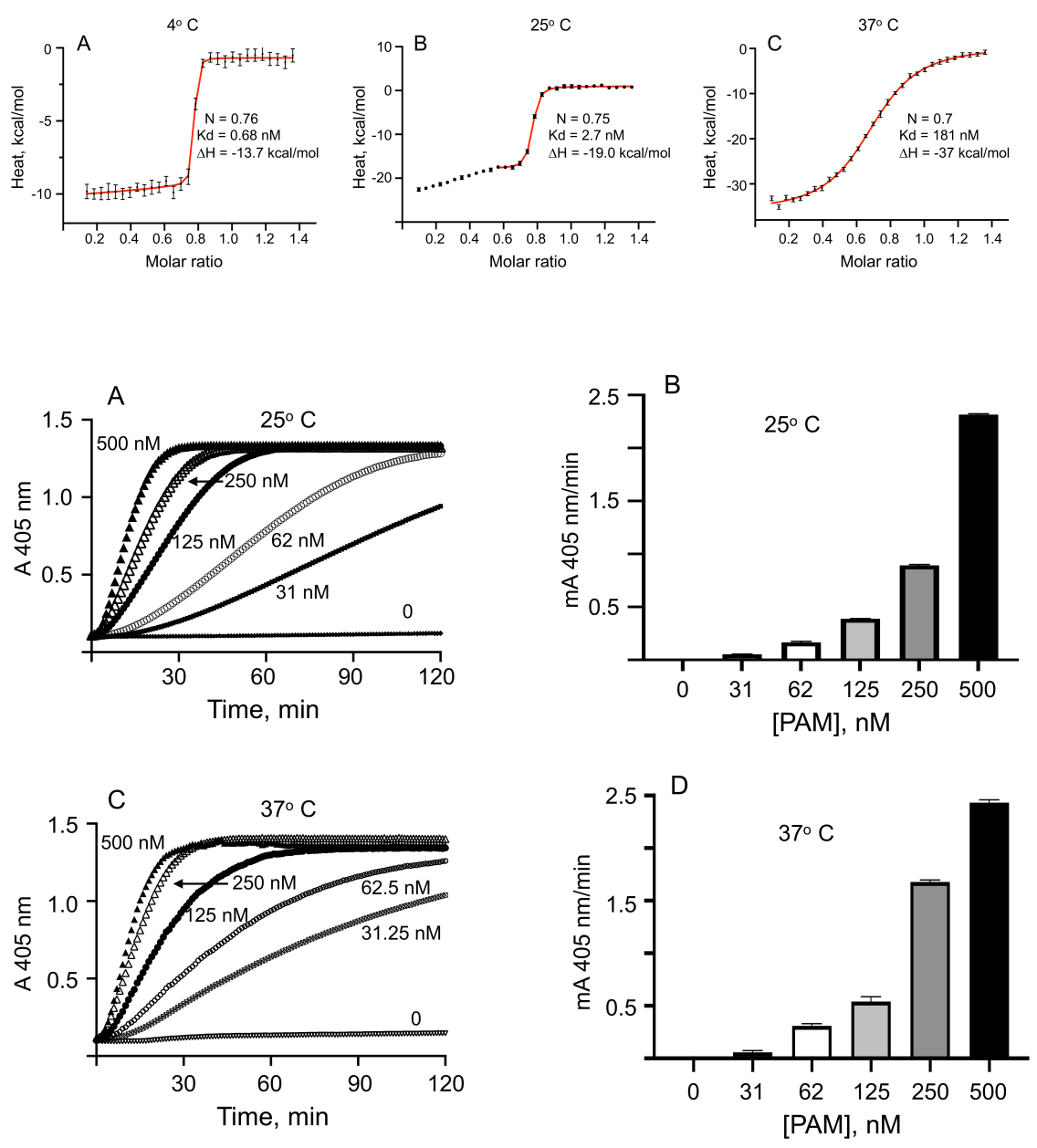